\title{
Gerakan sarapan sehat anak sekolah (sarasehan) untuk peningkatan pengetahuan ibu tentang sarapan sehat anak sekolah
}

Healthy breakfast movement to increase the mothers' knowledge on the primary school children's breakfast

Fatmah

Departemen Gizi Kesehatan Masyarakat, Fakultas Kesehatan Masyarakat Universitas Indonesia

\begin{abstract}
Background: Breakfast can meet energy requirement of school children to conduct their daily activity all day. But, in reality there are many school children who do not behave in a healthy breakfast that can meet the needs of $30 \%$ of energy. One of reason is lack of knowledge and practice of the mother in preparing a healthy breakfast for their children. Objective: To assess the influence of media outreach breakfast (booklets, flipchart, and short films) on the mothers' knowledge of healthy breakfast school children. Methods: Design of quasi-experimental one group pre-post test used in the study towards 186 mothers from ten the selected elementary school at Depok City. Mother's knowledge was measured through a questionnaire pre-post test. Results: There was increased in knowledge of mothers at the end of the study with the most correct answers given by the mother on the question of the type of food that should be avoided at breakfast. Increased knowledge of the mother before and after the study was differed significantly according to age groups ( $p<0.05)$. Older age of mother have better knowledge than younger. Conclusion: Knowledge of mothers on healthy breakfast can be improved through counseling using flipcharts, booklets, and short film.
\end{abstract}

KEY WORDS: age of mother; healthy breakfast; knowledge; mothers; school children

\begin{abstract}
ABSTRAK
Latar belakang: Sarapan merupakan salah satu cara untuk memberikan energi yang dibutuhkan oleh anak sekolah agar bisa beraktivitas seharian. Namun, kenyataannya masih banyak anak sekolah yang belum berperilaku sarapan sehat yang dapat memenuhi kebutuhan $30 \%$ energi. Salah satu penyebabnya adalah rendahnya pengetahuan dan praktik ibu dalam menyiapkan sarapan sehat bagi anak. Tujuan: Menilai pengaruh media penyuluhan sarapan (booklet, lembar balik, dan film pendek) terhadap peningkatan pengetahuan ibu tentang sarapan sehat anak sekolah. Metode: Desain quasi experimental one group pre-post test digunakan pada studi terhadap 186 ibu dari 10 SDN terpilih di seluruh kecamatan Kota Depok. Pengukuran pengetahuan ibu diukur melalui kuesioner pre-post test. Hasil: Terdapat kenaikan pengetahuan di akhir studi dengan jawaban benar paling banyak diberikan oleh ibu pada pertanyaan tentang jenis makanan yang harus dihindari saat sarapan. Peningkatan pengetahuan ibu sebelum dan setelah studi berbeda signifikan berdasarkan kelompok umur $(\mathrm{p}<0,05)$. Semakin tua usia ibu semakin baik pengetahuannya. Simpulan: Pengetahuan ibu tentang sarapan sehat dapat ditingkatkan melalui penyuluhan menggunakan booklet, lembar balik, dan film pendek.
\end{abstract}

KATA KUNCI: usia ibu; sarapan sehat; pengetahuan; ibu; anak sekolah

\section{PENDAHULUAN}

Salah satu isi pesan dari 13 Pesan Umum Gizi Seimbang (PUGS) dan Keluarga Sadar Gizi (Kadarzi) adalah biasakan sarapan pagi. Namun, masih banyak penduduk Indonesia yang tidak sarapan. Data Riset Kesehatan Dasar (Riskesdas) tahun 2010 menyatakan bahwa 26,1\% anak sekolah dasar (SD) hanya sarapan dengan air minum dan $44,6 \%$ anak SD yang sarapan hanya memperoleh asupan energi kurang dari 15\% kebutuhannya (1).

Sarapan pagi merupakan salah satu cara untuk memberikan energi yang dibutuhkan oleh tubuh agar bisa beraktivitas seharian. Jadi tidak ada alasan bagi anak

Korespondensi: Departemen Gizi Kesehatan Masyarakat, Fakultas Kesehatan Masyarakat Universitas Indonesia, Gedung F Lt. 2 Ruang F202 Kampus UI, Depok 16424, Telp. (021) 7863501, Fax. (021) 7863501,e-mail: ffatmah@ yahoo.com 
untuk tidak memperoleh hak sarapan paginya karena dapat meningkatkan konsentrasi pelajaran di sekolah, membuat anak bersemangat dalam melakukan berbagai aktivitas di pagi hari karena kebutuhan energi terpenuhi, mencegah penyakit perut, maag atau pusing, dapat memenuhi kebutuhan gizi yang seimbang untuk tubuh, mencegah obesitas, memberikan zat gizi yang dapat membantu pertumbuhan tubuh, dan meningkatkan kecerdasan anakanak, terutama jika diberi sarapan sehat dan bergizi. Namun, lebih baik lagi jika para orang tua khususnya ibu dapat memberikan sarapan dengan menu makanan sehat (2).

Anak usia 6-12 tahun membutuhkan asupan gizi lebih banyak dibandingkan dengan usia pertumbuhan lainnya. Agar perkembangannya optimal, anak-anak di usia tersebut memerlukan asupan gizi seimbang setiap harinya dengan mengkonsumsi makanan yang mengandung karbohidrat, protein, lemak, vitamin, dan mineral dalam pola makan yang teratur (3). Ibu dari anak sekolah usia 6-12 tahun merupakan target primer kegiatan intervensi yang berperan langsung dalam menentukan status gizi anaknya. Ibu merupakan gatekeeper yang membuka dan menutup jalan atau saluran informasi tentang pentingnya sarapan sehat. Peran ibu memiliki pengaruh besar dalam membentuk kebiasaan sarapan anak.

Sarapan pada anak usia ini memerlukan seseorang yang lebih dewasa untuk menyiapkan dan pada umumnya adalah tugas ibu. Selain berperan dalam membentuk kebiasaan sarapan, ibu juga berperan dalam menentukan menu sarapan yang baik untuk anak. Pendidikan dan pengetahuan gizi ibu menjadi dasar dalam membiasakan anak untuk sarapan serta mempengaruhi penentuan menu sarapan. Seorang ibu yang pendidikannya tinggi dan pengetahuannya baik diharapkan dapat memotivasi anak untuk sarapan dan menyiapkan sarapan yang cukup mengandung energi dan protein serta zat gizi lainnya. Hasil studi pada siswa SD di Kabupaten Kudus menemukan adanya hubungan antara pengetahuan ibu dengan kebiasaan sarapan siswa (4). Hasil penelitian di Amerika menunjukkan bahwa anak yang ibunya bekerja memiliki kebiasaan sarapan yang rendah daripada ibu tidak bekerja (5). Sementara penelitian di Yogyakarta menemukan bahwa 59,4\% sarapan disiapkan oleh ibu. Hal ini membuktikan pentingnya peran ibu dalam hal ketersediaan makanan di keluarga (6).
Oleh karena itu, perlu dilakukan suatu gerakan kampanye berjudul Gerakan Sarasehan (Sarapan Sehat Anak Sekolah) yang mendukung praktik sarapan sehat pada ibu-ibu anak usia 6-12 tahun. Tujuan intervensi adalah untuk meningkatkan pengetahuan ibu tentang sarapan sehat anak sekolah. Gerakan ini menitikberatkan pada kegiatan sosialisasi dan penyampaian pendidikan gizi termasuk praktik menu resep sarapan sehat untuk meningkatkan pengetahuan dan praktik ibu dalam menyediakan sarapan sehat bagi anak-anaknya. Strategi yang dilakukan dalam kegiatan kampaye adalah penyebaran leaflet dan flipchart, pemutaran slide dan iklan TV, serta seminar dan pelatihan teknik-teknik penyuluhan tentang sarapan sehat. Selanjutnya, ibu-ibu yang telah dilatih tersebut dididik menjadi kader/trainer/pelatih yang menyuluh kaum ibu di lingkungan tempat tinggalnya dan SD tempat anaknya bersekolah. Diseminasi informasi sarapan sehat dapat tercipta melalui penyebarluasan informasi tersebut oleh kader/trainer terlatih.

\section{BAHAN DAN METODE}

Desain quasy experimental one group pre-test post-test design digunakan dalam studi ini. Penelitian dilaksanakan pada bulan September 2014 - Juni 2015 pada 186 subjek yang memenuhi kriteria inklusi dan eksklusi. Kriteria inklusi yaitu ibu-ibu yang memiliki putera atau puteri berusia antara 10-11 tahun (kelas IV-V) dan bersedia mengikuti seluruh jalannya penelitian. Alasan pemilihan subjek berusia 10-11 tahun karena pada rentang usia ini adalah masa akhir anak-anak. Kriteria eksklusi adalah ibu-ibu yang tidak mengikuti kegiatan gerakan sarasehan sampai selesai dengan alasan apapun. Sebanyak 10 SDN terpilih secara acak berpartisipasi dalam penelitian ini mewakili 10 kecamatan se-Kota Depok (SDN Beji 2, SDN Bojongsari 2, SDN Cilodong 1, SDN Mekarsari 3, SDN Gandul 1, SDN Anyelir 2, SDN Mekarjaya 4, SDN Sindangkarsa 1, SDN Sawangan 01, dan SDN Krukut 3). Variabel terikat yang diukur adalah pengetahuan ibu tentang sarapan sehat anak sekolah sebelum dan setelah intervensi sedangkan variabel bebasnya adalah gerakan sarapan sehat anak sekolah (sarasehan) yaitu kegiatan penyuluhan gizi sarapan dengan media lembar balik, booklet, dan film pendek 
Gerakan sarasehan merupakan kegiatan intervensi untuk meningkatkan pengetahuan masyarakat tentang perlunya sarapan sehat anak sekolah. Intervensi diawali dengan seminar sehari tentang sarapan sehat melalui metode ceramah, diskusi kelompok, dan simulasi penyuluhan sarapan sehat menggunakan media cetak booklet, lembar balik, dan pemutaran film pendek. Pada saat gerakan sarasehan juga telah dibentuk 18 kelompok motivator dari ibu-ibu yang memiliki putera dan puteri yang bersekolah di 10 SDN tersebut. Diagram alur penelitian secara jelas ditampilkan dalam Gambar 1. Tugas kelompok motivator adalah untuk menyebarluaskan isi pesan sarapan sehat di tingkat masyarakat melalui kegiatan arisan, pengajian, posyandu lansia, posyandu balita, dan pertemuan orang tua murid di
SD. Selanjutnya, implementasi kegiatan oleh kelompok motivator dimonitor oleh tim peneliti Fakultas Kesehatan Masyarakat Universitas Indonesia melalui kunjungan ke lokasi kampanye sarapan di lingkungan masing-masing kelompok motivator.

Indikator keberhasilan peserta gerakan sarasehan ditinjau dari adanya peningkatan skor pre-post test dengan pengisian kuesioner sebelum dan setelah gerakan sarasehan. Kuesioner telah divalidasi oleh tim peneliti melalui kegiatan uji coba kuesioner pada ibuibu siswa siswi dari SDN yang berbeda dengan SDN peserta gerakan sarasehan. Keberhasilan pembentukan kelompok motivator dinilai dari implementasi penyuluhan sarapan sehat di lingkungan masyarakat terdekat. Metode dan pengetahuan yang telah ditransfer

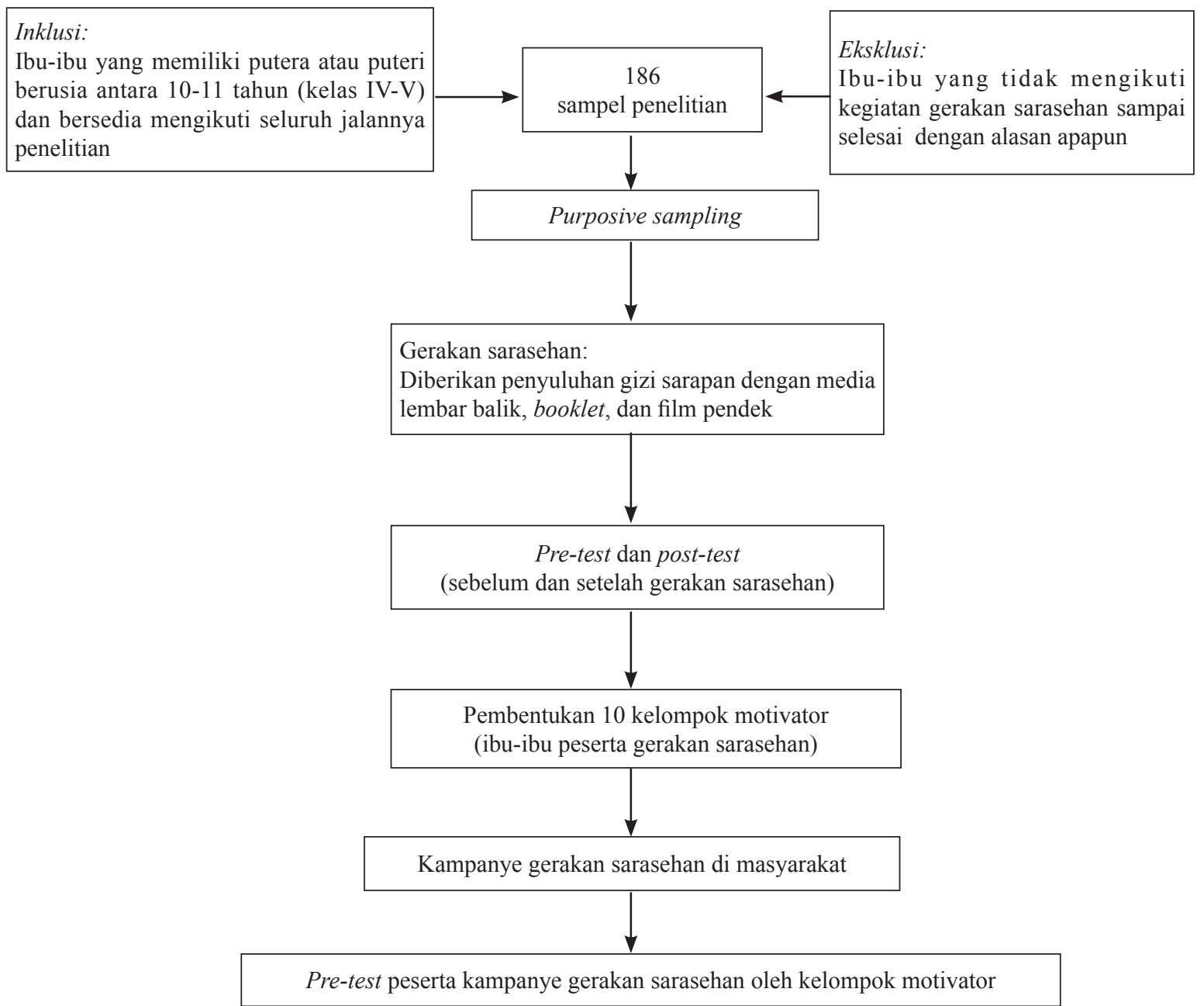

Gambar 1. Alur penelitian 
oleh tim peneliti kepada mitra sasaran program gerakan sarasehan adalah tentang keterampilan ibu-ibu dari siswa-siswi SDN terpilih untuk melakukan edukasi sarapan sehat dalam kelompok-kelompok motivator atau kelas-kelas penyuluhan di wilayahnya masingmasing. Bentuk edukasinya adalah penyuluhan tatap muka dengan alat bantu media cetak terdiri dari lembar balik dan booklet. Media visual berupa film iklan layanan masyarakat durasi 3 menit diputar oleh tim peneliti di sejumlah lokasi di lingkungan masingmasing kelompok motivator.

Kuesioner pre-post test untuk peserta gerakan sarasehan meliputi manfaat utama sarapan, kriteria sarapan sehat, contoh menu sarapan sehat, dampak tidak sarapan, serta gambaran perilaku sarapan anak-anaknya. Saat dilakukan kampanye sarapan sehat oleh kelompok motivator, maka tim peneliti juga mendistribusikan kuesioner pre-tes tentang pengetahuan ibu yang sama dengan kuesioner peserta pada saat gerakan sarasehan, tetapi tidak mengukur perubahan pengetahuan (post-test) karena hanya untuk memperoleh gambaran pengetahuan tentang sarapan sehat sebelum dilakukan kampanye oleh kelompok motivator.

Pengetahuan ibu diukur dari penilaian jawaban benar atas 12 pertanyaan dalam kuesioner pre-post test. Selisih skor jawaban yang benar diperoleh dari pengurangan skor jawaban benar post-test terhadap pre-test. Rerata dan standar deviasi (SD) jawaban benar dihitung untuk menilai rerata pengetahuan ibu tentang sarapan sehat. Statistik deskriptik dilakukan untuk memperoleh sebaran data distribusi frekuensi. Paired t-test dilakukan untuk menganalisis perbedaan rerata skor pengetahuan ibu sebelum dan setelah gerakan sarasehan.

\section{HASIL}

\section{Karakteristik subjek penelitian}

Tabel 1 menggambarkan mayoritas ibu berasal dari SDN Cilodong I dan diikuti oleh SDN Sawangan I. Minoritas ibu berasal dari SDN Mekarjaya 4 dan SDN Gandul 1. Kebanyakan ibu berusia antara 30-39 tahun dan diikuti oleh usia 40-49 tahun, tetapi masih ada yang berusia di atas 49 tahun. Pendidikan akhir didominasi oleh ibu dengan lulusan SLTA, tetapi ada juga yang tamat SD. Sebagian besar ibu tidak bekerja dan sisanya bekerja sebagai guru dan wiraswasta.

\section{Pengetahuan tentang sarapan}

Dua belas pertanyaan tentang sarapan sehat ditanyakan kepada peserta melalui kuesioner pre-post test. Ketika ditanyakan tentang manfaat utama sarapan bagi anak sekolah, hampir seluruh subjek menjawabnya dengan benar baik di awal maupun di akhir gerakan sarasehan. Jenis makanan yang harus dihindari saat sarapan adalah pertanyaan yang memiliki kenaikan skor paling tinggi di akhir gerakan sarasehan. Manfaat utama sarapan anak sekolah adalah pertanyaan yang paling sedikit mengalami kenaikan jawaban benar $(1,1 \%)$. Pertanyaan tentang jenis makanan yang harus dihindari saat sarapan paling banyak mengalami kenaikan skor nilai di akhir gerakan sarasehan $(37,1 \%)$, diikuti oleh pertanyaan cara mengatasi tidak sarapan $(28 \%)$, cara menyiapkan sarapan sehat anak sekolah $(17,8 \%)$, jenis buah yang paling baik dikonsumsi untuk sarapan (17,2\%), dan akibat tidak sarapan bagi anak sekolah (16,2\%).

Hasil penelitian menunjukkan rerata pengetahuan ibu tentang sarapan sehat yang meningkat signifikan $(\mathrm{p}=0,001)$ antara sebelum $(82 \pm 2,0)$ dan setelah gerakan sarasehan $(96 \pm 2,0)$. Sementara itu, rerata pengetahuan ibu dengan jawaban benar dari 12 pertanyaan disajikan pada Tabel 2. Selisih jawaban benar paling besar di

Tabel 1. Karakteristik demografi ibu (n=186)

\begin{tabular}{lcc}
\hline \multicolumn{1}{c}{ Variabel } & n & \% \\
\hline Usia ibu (tahun) & & \\
$20-29$ & 12 & 6,5 \\
$30-39$ & 98 & 52,7 \\
$40-49$ & 69 & 37,1 \\
$>49$ & 7 & 3,8 \\
Pendidikan ibu & & \\
Tamat SD & 12 & 6,5 \\
Tamat SLTP & 28 & 15,1 \\
Tamat SLTA & 112 & 60,2 \\
Akademi/PT & 34 & 18,3 \\
Pekerjaan ibu & & \\
IRT & 176 & 94,6 \\
Guru & 8 & 4,3 \\
Wiraswasta & 2 & 1,1 \\
\hline
\end{tabular}


Tabel 2. Rerata pengetahuan ibu dengan jawaban benar (12 item pertanyaan) tentang sarapan sebelum dan sesudah gerakan sarasehan berdasarkan karakteristik demografi ibu

\begin{tabular}{|c|c|c|c|c|c|}
\hline \multirow{2}{*}{$\begin{array}{c}\text { Karakteristik } \\
\text { demografi }\end{array}$} & \multicolumn{2}{|c|}{ Sebelum } & \multicolumn{2}{|c|}{ Setelah } & \multirow{2}{*}{$\mathbf{p}$} \\
\hline & Rerata & SD & Rerata & SD & \\
\hline Usia ibu (tahun) & & & & & $0,013^{*}$ \\
\hline $20-29$ & 8,7 & 1,8 & 9,4 & 2,1 & \\
\hline $30-39$ & 8,1 & 2,0 & 9,7 & 2,0 & \\
\hline $40-49$ & 8,4 & 2,0 & 9,5 & 2,0 & \\
\hline$>49$ & 8,0 & 2,2 & 10,7 & 1,7 & \\
\hline Pendidikan ibu & & & & & 0,747 \\
\hline Tamat SD & 6,3 & 3,0 & 7,5 & 2,8 & \\
\hline Tamat SLTP & 7,5 & 2,0 & 9,0 & 2,0 & \\
\hline Tamat SLTA & 8,5 & 1,9 & 9,8 & 1,9 & \\
\hline Akademi/PT & 8,6 & 1,7 & 10,2 & 1,6 & \\
\hline Pekerjaan ibu & & & & & 0,672 \\
\hline IRT & 8,1 & 2,0 & 9,6 & 2,0 & \\
\hline $\begin{array}{l}\text { Guru/ } \\
\text { wiraswasta }\end{array}$ & 9,6 & 1,1 & 10,8 & 1,1 & \\
\hline
\end{tabular}

$*$ bermakna $(\mathrm{p}<0,05)$

akhir gerakan sarasehan ditemukan pada kelompok ibu berusia di atas 49 tahun. Ibu dengan tingkat pendidikan akhir akademi/perguruan tinggi dan ibu tidak bekerja juga mempunyai selisih jawaban benar paling tinggi sebelum dan setelah gerakan sarasehan. Ada perbedaan peningkatan pengetahuan ibu sebelum dan setelah gerakan sarasehan berdasarkan kelompok usia. Makin tinggi usia ibu makin besar peningkatan pengetahuannya. Meskipun tidak terdapat perbedaan signifikan perubahan pengetahuan ibu berdasarkan pendidikan akhir dan status pekerjaan, tetapi ada kecenderungan ibu yang berlatarbelakang pendidikan akhir akademi/perguruan tinggi mengalami perubahan rerata pengetahuan yang lebih baik dibandingkan dengan peserta yang tamat SD, SMP, dan SMA. Status pekerjaan peserta sebagai ibu rumah tangga/tidak bekerja memiliki peningkatan rerata pengetahuan sedikit lebih baik daripada peserta yang bekerja sebagai guru/wiraswasta.

\section{Perilaku ibu dalam praktik sarapan anak sekolah}

Dari total 186 ibu peserta gerakan sarasehan, sebanyak 26,3\% ibu menyebutkan anaknya yang bersekolah di SD lokasi penelitian tidak terbiasa sarapan. Sebagian besar ibu beralasan tidak sempat menyiapkan sarapan dan sisanya karena anaknya tidak suka sarapan dan kurangnya pengetahuan ibu dalam menyiapkan sarapan. Untuk mengganti sarapan di rumah, maka ibu memberikan uang jajan atau bekal kue-kue dari rumah untuk anaknya ke sekolah.

Mayoritas ibu menyebutkan bahwa kriteria sarapan sehat adalah yang telah memenuhi unsur-unsur gizi seimbang dan 4 sehat 5 sempurna. Hanya sebagian kecil ibu yang menganggap sarapan sehat bila memenuhi 30\% kebutuhan energi anak sekolah. Sementara untuk menu sarapan sehat, kebanyakan ibu menyatakan nasi goreng; nasi, lauk, sayur, buah, susu; susu dan roti; dan energen adalah menu sarapan yang sehat. Variasi menu sarapan dibutuhkan oleh ibu untuk mencegah kebosanan anak dan meningkatkan minat anak untuk sarapan.

\section{Monitoring kampanye sarasehan oleh kelompok motivator}

Kelompok motivator telah melakukan kampanye pada 176 orang di lingkungan sekitarnya melalui kegiatan posyandu balita, posyandu lansia, pengajian, arisan, SD negeri, dan SD swasta. Sebelum diberikan penyuluhan, peserta diukur pengetahuan sarapan sehatnya dengan kuesioner pre-test. Tujuan penilaian pengetahuan adalah untuk memperoleh gambaran pengetahuan tentang sarapan sehat sebelum dilakukan kampanye oleh kelompok motivator.

Sejumlah kegiatan penyuluhan sarapan sehat oleh kelompok motivator di lingkungan masyarakatnya, paling sering dilakukan adalah 1 kali dalam sebulan. Sebagian besar peserta kampanye Sarasehan oleh kelompok motivator berusia antara 30-39 tahun, tamat SMA, dan tidak bekerja. Rerata pengetahuan peserta berhubungan dengan karakteristik demografi yang meliputi usia, jenis pekerjaan, dan pendidikan akhir $(\mathrm{p}<0,05)$. Jawaban peserta yang paling banyak benar adalah manfaat utama sarapan bagi anak sekolah, diikuti tips agar sarapan disukai oleh anak, dan fungsi lain dari sarapan. Cara mengatasi tidak sarapan merupakan pertanyaan yang paling sedikit diketahui jawabannya oleh peserta kampanye sarapan oleh kelompok motivator (Tabel 3).

\section{BAHASAN}

Peningkatan rerata pengetahuan ibu peserta gerakan sarasehan dalam studi ini sejalan dengan studi 
Tabel 3. Pengetahuan peserta kampanye Sarasehan oleh kelompok motivator dengan jawaban benar tentang sarapan $(n=176)$

\begin{tabular}{lcccc}
\hline \multirow{2}{*}{\multicolumn{1}{c}{ Pengetahuan sarapan }} & \multicolumn{2}{c}{ Salah } & \multicolumn{2}{c}{ Benar } \\
\cline { 2 - 5 } & $\mathbf{n}$ & $\mathbf{\%}$ & $\mathbf{n}$ & $\mathbf{\%}$ \\
\hline Manfaat utama sarapan bagi anak SD & 6 & 3,4 & 170 & 96,6 \\
Kriteria sarapan yang sehat bagi anak SD & 46 & 26,1 & 130 & 73,9 \\
Cara menyiapkan sarapan sehat bagi anak SD & 40 & 22,7 & 136 & 77,3 \\
Contoh menu sarapan sehat untuk anak sekolah & 66 & 37,5 & 110 & 62,5 \\
Sarapan pagi harus memenuhi kebutuhan energi & 35 & 19,9 & 141 & 80,1 \\
Tips agar sarapan disukai anak & 29 & 16,5 & 147 & 83,5 \\
Fungsi lain dari sarapan pagi & 29 & 16,5 & 147 & 83,5 \\
Akibat tidak sarapan bagi anak SD & 72 & 40,9 & 104 & 59,1 \\
Cara mengatasi tidak sarapan & 132 & 75,0 & 44 & 25,0 \\
Sarapan yang baik harus sesuai dengan pedoman gizi & 52 & 29,5 & 124 & 70,5 \\
Jenis makanan yang harus dihindari saat sarapan pagi & 117 & 66,5 & 59 & 33,5 \\
Jenis buah-buahan yang paling baik untuk sarapan & 42 & 23,9 & 134 & 76,1 \\
\hline
\end{tabular}

pengaruh intervensi media komik pada pengetahuan sarapan anak SD di Kabupaten Bogor (7) serta studi sejenis pada ibu di Kabupaten Bogor tahun $2014(8,9)$. Ibu perlu memiliki pengetahuan memadai melalui penyerapan informasi dari media cetak maupun visual. Perilaku gizi harus didasari oleh pengetahuan gizi yang baik untuk mendorong perilaku ibu dalam menyiapkan sarapan sehat bagi anaknya. Hasil penelitian ini menunjukkan perbedaan pengetahuan ibu saat sebelum dan setelah gerakan sarasehan yang signifikan meskipun peningkatan nilainya tidak begitu besar. Hal ini mungkin disebabkan oleh sudah baiknya pengetahuan ibu di awal yaitu skor sebesar 80 sehingga tidak banyak mengalami kenaikan skor di akhir. Pengetahuan yang baik diperoleh dari prediktor pengetahuan awal sehingga pengetahuan awal seseorang sebelum menerima intervensi menentukan seberapa tinggi kenaikan skor pengetahuan setelah intervensi $(10,11)$.

Temuan studi ini sejalan dengan studi pada kelompok ibu menyusui di Cina yang diberikan pendidikan gizi (12). Demikian juga dengan studi pada kelompok pengasuh balita di Uganda yang menemukan adanya peningkatan pengetahuan pemberian makanan pendamping air susu ibu (MP-ASI) (13). Media penyuluhan lembar balik dan booklet telah diakui dapat meningkatkan pengetahuan individu dalam suatu intervensi. Hal ini dibuktikan oleh studi sebelumnya yang menunjukkan adanya perbedaan peningkatan pengetahuan ibu di Amerika Serikat setelah diintervensi dengan media lembar balik dan brosur (14). Film pendek berperan pula dalam mengubah pengetahuan individu. Keunggulan media ini adalah dapat memberikan realita yang sulit direkam kembali oleh mata dan pikiran sasaran (15). Adanya pengaruh media film pendek dan booklet pada peningkatan pengetahuan ibu tentang sarapan didukung oleh studi serupa pada ibu-ibu siswa-siswi SDN Cimanggis 2 dan 3 Kota Depok. Terdapat perbedaan pengetahuan gizi ibu setelah diintervensi dengan kedua jenis media tersebut (16). Hal ini sejalan dengan dua studi sebelumnya yaitu studi pertama menggunakan booklet dan DVD untuk kelompok intervensi dan studi kedua menggunakan media audio visual. Kedua studi menggambarkan peningkatan pengetahuan ibu setelah diberikan penyuluhan gizi dengan media audio visual $(17,18)$. Mata merupakan jenis pancaindera yang paling banyak menyalurkan pengetahuan ke otak (75-87\%), sisanya melalui pancaindera yang lain seperti telinga (13-25\%). Semakin banyak yang dirangsang maka masuknya informasi akan semakin mudah. Media visual memberikan rangsangan melalui mata dan telinga. Perpaduan saluran informasi melalui mata yang mencapai $75 \%$ dan telinga $13 \%$ akan memberikan rangsangan yang cukup baik sehingga dapat memberikan hasil yang optimal (19).

Pada studi ini, peningkatan pengetahuan berbeda secara signifikan berdasarkan kelompok usia. Usia berperan dalam peningkatan pengetahuan seseorang karena penambahan usia akan mematangkan pola 
pikirnya sehingga pengetahuan yang diperoleh semakin baik (20). Rentang usia ibu dalam studi ini tergolong usia produktif sehingga masih memiliki daya pikir yang baik. Meskipun tidak ada perbedaan perubahan pengetahuan ibu sesuai pendidikan akhir, tetapi ibu dengan pendidikan akademi/perguruan tinggi memiliki perubahan pengetahuan lebih baik dibandingkan pendidikan menengah atau rendah (SD). Pendidikan akhir mempengaruhi perubahan tingkat pengetahuan individu. Seseorang yang memiliki pendidikan tinggi akan cenderung mencari tahu tentang suatu informasi. Tingkat pendidikan yang lebih tinggi akan lebih mudah menyerap informasi dan mengimplementasikannya dalam perilaku dan gaya hidup, khususnya dalam hal kesehatan dan gizi (21). Temuan studi ini tidak sejalan dengan 2 studi yang menyatakan tingkat pendidikan akhir mempengaruhi pengetahuan ibu $(22,23)$.

Ibu bekerja dengan tidak bekerja memiliki peningkatan pengetahuan yang sama tentang sarapan sehat sebelum dan setelah intervensi. Namun, ibu yang hanya bekerja di rumah sebagai ibu rumah tangga mengalami kenaikan skor pengetahuan sedikit lebih baik daripada ibu yang berprofesi sebagai guru dan wiraswasta. Ibu yang tidak bekerja mungkin memiliki banyak waktu luang untuk memperoleh akses informasi tentang sarapan dari media cetak dan media visual. Berdasarkan hasil penelitian ini, dapat disimpulkan bahwa pengetahuan ibu tentang sarapan sehat dapat ditingkatkan melalui penyuluhan dan kampanye sarapan dengan media cetak berupa booklet dan lembar balik serta media visual film pendek.

Studi ini memiliki beberapa keterbatasan yaitu, 1) tidak ada kelompok pembanding sebagai kontrol yang tidak diberikan intervensi maupun kelompok pembanding yang diberikan salah satu dari ketiga jenis media kampanye yaitu booklet, lembar balik, dan film pendek; 2) pengetahuan post-test peserta kampanye sarapan oleh kelompok motivator tidak diukur karena keterbatasan waktu dan peserta selalu ingin cepat pulang pasca-kampanye; 3) perubahan perilaku/praktik sarapan anak sekolah oleh ibu peserta gerakan sarasehan tidak diukur/dinilai.

\section{SIMPULAN DAN SARAN}

Pengetahuan ibu tentang sarapan sehat dapat ditingkatkan melalui penyuluhan menggunakan booklet, lembar balik, dan film pendek. Peningkatan pengetahuan ibu sebelum dan setelah gerakan sarasehan berbeda signifikan berdasarkan kelompok umur $(\mathrm{p}<0,05)$. Disarankan agar kegiatan intervensi dapat disebarluaskan di sekolah-sekolah lain yang belum mendapatkan kesempatan mengikuti gerakan sarasehan. Evaluasi keberhasilan studi melalui penilaian praktik perilaku ibu dalam menyiapkan sarapan pasca-intervensi perlu dilakukan untuk mengukur keberhasilan intervensi.

\section{UCAPAN TERIMA KASIH}

Ucapan terima kasih ditujukan pada Direktorat Riset dan Pengabdian Masyarakat (DRPM) Universitas Indonesia yang telah mendanai kegiatan ini melalui Hibah Community Engagement Grants (CEGs) Universitas Indonesia tahun 2014.

\section{RUJUKAN}

1. Departemen Kesehatan. Riset kesehatan dasar 2010. [series online] 2010 [cited 2014 Jul]. Available from: URL: http://www.riskesdas.litbang.depkes.go.id/download/ TabelRiskesdas2010.pdf.

2. UNICEF. Ringkasan kajian gizi ibu dan anak. [series online] 2012 [cited 2014 Jul]. Available from: http://www.unicef.org/ indonesia/id/A6___B_Ringkasan_Kajian_Gizi.pdf.

3. Hardinsyah, Aries M. Jenis pangan sarapan dan perannya dalam asupan gizi harian anak usia 6-12 tahun di Indonesia. Jurnal Gizi dan Pangan 2012;7(2):89-96.

4. Rohayati I. Beberapa faktor yang berhubungan dengan kebiasaan sarapan dan prestasi belajar siswa SD 2 Jepang Kecamatan Mejobo Kabupaten Kudus [Skripsi]. Semarang: Universitas Diponegoro; 2003.

5. Siega R, Popkin BM, Carson T. Trends breakfast consumption for children in the United State from 1965 to 1991. Am J Clin Nutr 1998;67(4):748S-56S.

6. Ramadhani A, Auliana R. Kebiasaan sarapan pagi siswa kelas V SDN Caturnunggal IV Depok Sleman Yogyakarta. Ejournal Universitas Negeri Yogyakarta [series online] 2014 [cited 2014 Jul];3(1). Available from: URL: http:// journal.student.uny.ac.id/jurnal/artikel/7787/27/821 2014 
7. Briawan D, Ekayanti I, Koerniawati RD. Pengaruh media kampanye sarapan sehat terhadap perubahan pengetahuan, sikap, dan kebiasaan sarapan anak sekolah dasar di Kabupaten Bogor. Jurnal Gizi dan Pangan 2013;8(2):11522.

8. Ekayanti I, Briawan D, Imas D. Perbedaan penggunaan media pendidikan terhadap perubahan pengetahuan dan sikap ibu dalam sarapan anak sekolah dasar di Kabupaten Bogor. Jurnal Gizi dan Pangan 2013;8(2):109-14.

9. Khomsan A, Faisal A, Mudjajanto E. Pengetahuan, sikap dan praktik ibu peserta posyandu. Jurnal Gizi dan Pangan 2009;4(1):33-41.

10. Notoatmojo S. Promosi kesehatan teori dan aplikasi. Jakarta: PT. Rineka Cipta; 2005.

11. Oshgah M, Danaei SM, Ghahremani Y, Pajuhi N, Boushehri SG. Impact of an educational leaflet on parents' knowledge and awareness of children's orthodontic problems in Shiraz. East Mediterr Health J 2011;7(2):121-5.

12. Yin SA, Li N, Yan ZY, Pan L, Lai JQ, Zhao XF. Effects of nutritional education on improvement of nutritional knowledge of infant's mothers in rural area in China. Zhonghua Yu Fang Yi Xue Za Zhi 2009;43(2):103-7.

13. Josephine N, Agnes N, Archileo N, Kaaya, George N. Nutrition education influences child feeding knowledge, attitudes and practices of caregivers in Uganda. American Journal of Health Research 2015;3(2):82-90.

14. Hyden C, Kahn R, Bonuck K. Bottle-weaning intervention tools: the "how" and "why" of a WIC-based educational flipchart, parent brochure, and website. Health Promot Pract 2012;4(1):57-80.

15. Smith KL. Handbook of visual communication: theory, methods, and media. New York: Routledge; 2005.
16. Leiliana I. Pengaruh media visual dan cetak pada pengetahuan gizi, sikap, dan perilaku ibu terhadap sarapan sehat anak sekolah di SDN terpilih Kota Depok Tahun 2013. [Tesis]. Depok: Fakultas Kesehatan Masyarakat Universitas Indonesia; 2013.

17. Barr RG, Rivara FP, Barr M, Cummings P, Taylor J, MeredithBenitz E. Effectiveness of educational materials designed to change knowledge and behaviors regarding crying and shaken-baby syndrome in mothers of newborns: a randomized controlled trial. Pediatrics 2009;123(3):972-80.

18. Rahmawati I, Toto S,Ira P. Pengaruh penyuluhan dengan media audio visual terhadap peningkatan pengetahuan, sikap, dan perilaku gizi ibu balita gizi kurang dan buruk di Kabupaten Kotawaringin Barat Propinsi Kalimantan Tengah. Jurnal Gizi Klinik Indonesia 2007;4(2):69-77.

19. Maulana. Promosi kesehatan. Jakarta: EGC; 2009.

20. Meliono I. Pengetahuan. In: MPKT Modul 1. Jakarta: FEUI, 2007.

21. Atmarita, Tatang S. Fallah. Analisis situasi gizi dan kesehatan masyarakat. [serial online] 2004 [cited 2013 April]. Available from: URL: http://118.96.130.34/ aridata_web/how $/ \mathrm{k} / \mathrm{kesehatan} / 4$ analisis_gizi.pdf

22. Garini W. Pengaruh intervensi VCD metode perawatan bayi terhadap pengetahuan ibu bayi berat badan lahir rendah di RSUD Ciawi Bogor Jawa Barat. [serial online] 2004 [cited 2013 April]. Available from: URL: http://www. digilib.ui.ac.id/opac/themes/libri2/detail.jsp?id=124680.

23. Jayanti, Christin. Efektivitas penyuluhan dan media leaflet terhadap pengetahuan dan sikap ibu balita gizi buruk di Kecamatan Medan Denai [Tesis]. Medan: Program Studi S2 Ilmu Kesehatan Masyarakat Universitas Sumatera Utara; 2010. 